\title{
The Effect of Baseline Rescue Medication Use on Efficacy and Safety of Nebulized Glycopyrrolate Treatment in Patients with COPD from the GOLDEN 3 and 4 Studies [Corrigendum]
}

\author{
Donohue JF, Ozol-Godfrey A, Goodin T, Sanjar S. Int $J$ The correct Figure 4 is shown below. The authors apol- \\ Chron Obstruct Pulmon Dis. 2020;15:745-754. \\ ogize for this error.
}

The authors have advised there is an error in Figure 4 on page 751. The Q2 subgroup of the placebo arm has the label of " -0.012 " which should read " 0.012 ".

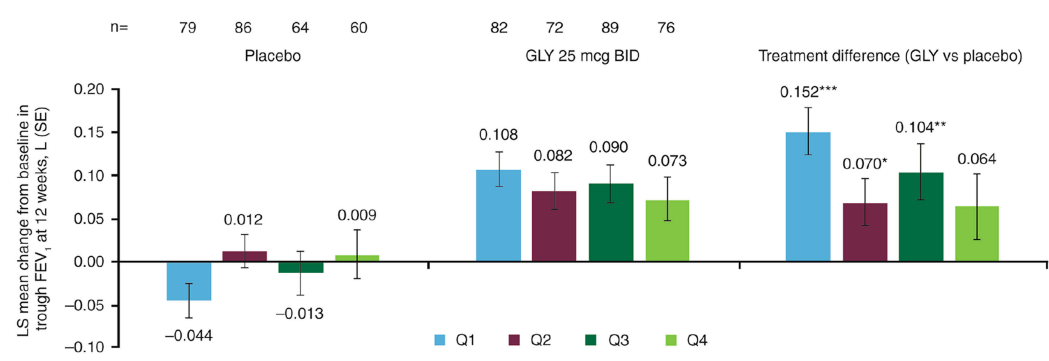

Figure 4 Pooled analysis of change from baseline in trough $\mathrm{FEV}_{\mathrm{I}}$ at 12 weeks by baseline rescue medication use subgroup (ITT population).

Notes: $* p<0.05, * * p<0.01, * * * p<0.001$ versus placebo; $n$-values represent the number of patients with on-treatment data at week 12 .

Abbreviations: BID, twice daily; FEV , forced expiratory volume in I second; GLY, nebulized glycopyrrolate; ITT, intent-to-treat; LS, least squares; Q, quarter; SE, standard error.

\section{Publish your work in this journal}

The International Journal of COPD is an international, peer-reviewed journal of therapeutics and pharmacology focusing on concise rapid reporting of clinical studies and reviews in COPD. Special focus is given to the pathophysiological processes underlying the disease, intervention programs, patient focused education, and self management protocols. This journal is indexed on PubMed Central, MedLine and CAS. The manuscript management system is completely online and includes a very quick and fair peer-review system, which is all easy to use. Visit http://www.dovepress.com/testimonials.php to read real quotes from published authors. 